\title{
PENGARUH KONSELING KELOMPOK PENDEKATAN RATIONAL EMOTIVE BEHAVIOUR THERAPY TERHADAP KECEMASAN BERPENDAPAT SISWA KELAS VII-5 SMP NEGERI 3 TANJUNGBALAI T.A 2016/2017
}

\author{
Dra. Pastiria Sembiring, M.Pd.,Kons \\ Etika Rahmi \\ Jurusan PPB Prodi Bimbingan dan Konseling FIP UNIMED
}

\begin{abstract}
Abstrak
Rumusan masalah dalam penelitian ini adalah: Apakah ada pengaruh layanan konseling kelompok pendekatan Rational Emotif Behaviour Terapy terhadap kecemasan berpendapat siswa kelas VII-5 SMP Negeri 3 Tanjungbalai Taun Ajaran 2016/2017. Tujuan penelitian ini adalah untuk mengetahui pengaruh layanan konseling kelompok pendekatan Rational Emotif Behaviour Terapy terhadap kecemasan berpendapat siswa kelas VII-5 SMP Negeri 3 Tanjungbalai Taun Ajaran 2016/2017. Metode yang digunakan dala penelitian ini adalah metode kuantitatif. Jenis penelitian ini adalah eksperimen semu dengan design pre-test dan post-test. Sampel penelitian ini adalah siswa kelas VII-5 yang terdiri dari 8 orang siswa dan populasi dalam penelitian ini adalah 30 siswa. Instrumen yang digunakan adalah angket/skala kecemasan berpendapat siswa, instrumen diberikan seblum dan sesudah pelaksanaan konseling kelompok pendekatan rational emotif behaviour terapy. Teknik analisis data dalam penelitian ini menggunakan uji Wilcoxon. Hasil analisa data yang diperoleh adalah nilai $\mathrm{J}$ hitung $=17,5$ dengan $a=0,05$ dan $\mathrm{n}=8$, maka berdasarkan daftar tabel Jtabel $=$ 4. Dengan demikian J hitung > J tabel $(17,5>4$ ). Data pre-test diperoleh rata-rata 97,5 (kecemasan berpendapat tinggi) sedangkan setelah pemberian layanan konseling kelompok pendekatan Rational Emotif Behaviour Terapy lebih sebesar 42 atau 43,07\%. Hal ini menunjukkan ada pengaruh layanan konseling kelompok pendekatan Rational Emotif Behaviour Terapy terhadap kecemasan berpendapat siswa kelas VII-5 SMP Negeri 3 Tanjung Balai T.A 2016/2017 atau hipotesis diterima.

Kata kunci : Kecemasan berpendapat, Konseling kelompok, Pendekatan Rational Emotif Behaviour Terapy PENDAHULUAN

Namun tidak sedikit di kalangan

Dalam pendidikan kegiatan belajar merupakan kegiatan yang paling pokok di sekolah, ini berarti berhasil tidaknya pencapaian tujuan pendidikan banyak bergantung kepada bagaimana proses belajar yang dialami oleh siswa. Dalam proses belajar mengajar seringkali guru bidang studi mengukur kemampuan siswa-siswanya dalam menguasai pelajaran yang telah disampaikan dengan meminta siswa-siswi mengutarakan pendapat, baik itu dalam bentuk pertanyaan maupun dalam bentuk pernyataan. siswa yang cemas, takut, gemetaran bahkan keringat dingin dan pucat ketika guru meminta mereka mengutarakan pendapat, menjelaskan pelajaran dan menanggapi pertanyaan di depan kelas. Gejala psikologis ini sering terjadi di kalangan siswa bahkan disetiap kelas terdapat siswa yang merasakan hal seperi di atas, diantara mereka banyak yang beralasan kecemasan yang dirasakan itu muncul dengan sendirinya. Berdasarkan pengalaman peneliti ketika melakukan program pelatihan lapangan terpadu PPLT dari hasil wawancara dengan guru
\end{abstract}


bimbingan konseling terdapat banyak siswa yang mengalami kecemasan ketika guru meminta mereka berbicara dan berpendapat didepan kelas.

Kecemasan bukanlah permasalahan yang biasa dan tidak boleh diabaikan begitu saja, permasalahan kecemasan yang dialami siswa saat ini akan berdampak pada masa sekarang dan masa depannya. Peneliti menganggap penting melakuan penelitian ini, jika tidak permasalahan tentang kecemasan yang dialami siswa saat ini akan terus meningkat dan berdampak pada yang lain.

Adapun gejala-gejala kecemasan yang terjadi pada siswa saat ini menurut Kaplan, Sadock, \& Grebb (Fitri Fauziah \& Julianti Widury, 2007:74) adalah cemas mengutarakan pendapat di dalam kelas, cemas ketika menghadapi ujian lisan, cemas ketika guru menyuruh mengerjakan soal didepan kelas. Jika permasalahan kecemaan ini terus diabaikan maka siswa akan sulit melakukan pengembagan diri, siswa akan pesimis, dan sulit berprestasi.

Melihat dari sisi patologis permasalahan kecemasan ini tampaknya menjadi sesuatu yang wajar terjadi dalam kehidupan sehari-hari. Ini dengan alasan bahwa kecemasan umum merupakan gejala psikologis yang pastinya terjadi pada setiap siswa. Hanya saja persoalan yang dianggap wajar tersbut mejadi sebuah fenomena patologis ketika kecemasan itu berlebihan. Kecemasan ini menghasilkan pengaruh negatif pada diri siswa, salah satunya dalam bidang akademiknya. Sebaliknya jika permasalahan kecemasan ini dapat diatasi siswa akan percaya diri, berprestasi, tidak mudah menyerah, dan siap bersaing di bidang ilmunya.

Di dalam bimbingan konseling, siswa dianggap bermasalah ketika tidak dapat menjalani kehidupan efektif sehari-hari (KES), seperti permasalahan kecemasan yang terjadi pada siswa saat ini yang sangat berdampak negatif, ada beberapa alternatif pemberian bantuan yang dapat dilakukan konselor untuk membantu siswa yang mengalami permasaahan ini seperti melakukan konseling individual, layanan informasi dan konseling kelompok. Pada penelitian ini peneliti memadang permasalahan kecemasan ini harus segera diselesaikan melalui salah satu layanan konseling yaitu konseling kelompok yang menggunakan pendekatan Rational Emotive Behaviour Terapy.

Berdasarkan latar belakang di atas maka peneliti akan melakukan penelitian dengan judul "Pengaruh konseling kelompok pendekatan Rational Emotive Behaviour Terapy terhadap kecemasan berpendapat siswa kelas VII-5 SMP 
Negeri 3 Tanjungbalai Tahun Ajaran 2016/2017"

\section{KAJIAN PUSTAKA}

Dalam konseling kelompok pendekatan REBT ini klien yang di hadapi bukanlah bersifat individual tetapi terdiri dari beberapa orang yang mengalami masalah akan bersama-sama memanfaatkan dinamika kelompok untuk memebahas topik/permasalahan kecemasan berpendapat, dimana di dalam pendekatan REBT manusia dipandang memiliki rasional beleive dan irrasional beleive yang akan mempengaruhi tigkah laku (kecemasan berpendapat). Dengan adanya hubungan yang interaktif tersebut anggota kelompok akan merasa lebih mudah dan leluasa karena anggotanya merupakan teman sebaya mereka sendiri. Selain itu dengan melakukan konseling kelompok yang memanfaatkan dinamika kelompok ini, siswa juga belajar untuk memahami dan mengendalikan diri sendiri, memahami orang lain, saling bertukar pendapat tentang masalah kecemasan berpendapat. Fenomena ini dapat dimaknai sebagai petunjuk yang mengandung implikasi bahwa interaksi dan dinamika yang tumbuh dalam konseling kelompok diharapkan dapat digunakan untuk mengurangi kecemasan berpendapat siswa.
Dalam proses konseling kelompok yang dilakukan nanti akan membahas permsalah kecemasan berpendapat yang merupakan (irrasional beleive) yang menghasilkan tingkah laku (behaviour) seperti ketakutan ketika disuruh guru menjelaskan pelajaran di depan kelas, menangis, lari atau bahkan cabut dari kelas. Pemimpin kelompok akan melaksanakan proses konseling kelompk sesuai teori REBT dengan mengubah irrasional beleive menjadi rasional beleive yang mempengaruhi tingkah laku (behaviour) anggota kelompok.

Tujuan konseling kelompok tersebut secara umum adalah untuk mengurangi kecemasan berpendapat siswa. Apabila konseling kelompok ini menurut persepsi siswa bermanfaat, maka konseling kelompok yang diberikan diharapkan dapat memberikan kontribusi terhadap berkurangnya kecemasan siswa dalam berpendapat.

Adapun hipotesis penelitian ini adalah ada pengaruh konseling kelompok pendekatan rational emotive behaviour terapy terhadap kecemasan berpendapat siswa kelas VII-5 SMP Negeri 3 Tanjungbalai.

\section{METODE PENELITIAN}

Jenis penelitian ini adalah quasi experiment (eksperimen semu) dengan 
menggunakan one group design pre-test and post-test.

Populasi dalam penelitian ini adalah seluruh siswa Kelas VII-5 semester 4 SMP Negeri 3 Tanjungbalai Tahun ajaran 2016/2017 yang berjumlah 30 siswa.

Sample penelitian ini diperoleh dari angket yang diberikan kepada siswa Kelas VII-5, berdasarkan hasil analisis angket tersebut yang mendapat skor kecemasan berpendapat yang tinggi sebanyak 8 siswa, maka itu yang akan menjadi sampel penelitian ini. Adapun teknik pengumpulan data yang digunakan pada penilitian ini adalah: menggunakan observasi partisipan, wawancara, dokumentasi dan angket.

Adapun teknik analisis data yang digunakan dalam peneitian ini adalah dengan menggunakan statistik non parameter yaitu dengan uji wilcoxon, uji satu pihak “'test ranking- bertanda wilcoxon yaitu dengan mencari perbedaan mean pretest dan posttest.

\section{HASIL DAN PEMBAHASAN}

Data dalam penelitian penlitian diproleh degan melakukan pengukuran pada kecemasan berpendapat siswa dengan melakukan wawancara tidak berstruktur serta menyebarkan sebelum pemberian layanan konseling kelompok pendekatan Rational Emotif Behaviour Terapy (pre-test) dan setelah pemberian konseling kelompok pendekatan Rational Emotif Behaviour Terapy (post-test). Selanjutnya data-data ni ini akan diolah dengan uji wilcoxon. Sebelum mengemukakan data diatas, dikemukaka terlebih dahulu gambaran umum lokasi penelitian.

Penelitian ini dilaksanakan di SMP Negeri 3 Tajungbalai yang berlokasi di Jalan Pematang Pasir, Kelurahan Pematang Pasir, Kecamatan Teluk Nibung, SMP Negeri 3 Tanjungbalai memiliki luas $2265,7 \mathrm{~m} 2$. Suasana sekolah sejuk, nyaman, banyak pepohonan dan kondusif serta mendukung proses belajar mengajar dengan baik. Sekolah ini memiliki 19 ruang kelas, 3 laboratorium, 1 ruang perpustakaan, 1 kantor kepala sekolah, 1 kanto wakil kepala sekolah,1 kantor dewan guru, 1 ruang tata usaha, 1 ruang $\mathrm{BK}, 1$ ruang UKS, 1 Musholla, 1 pos satpam, 2 kamar mandi guru, 9 kamar mandi siswa, 4 kantin, 1 gudang, 1 rumah penjaga sekolah, dan sekolah ini memiliki lapangan olahraga yang cukup luas.

SMP Negeri 3 Tanjungbalai dipimpin oleh Bapak Syafii, S.Pd. MM Jumlah keseluruhan uru di SMP Negeri 3 Tanjungbalai sebanyak 36 guru, 2 diantaranya adaala guru bimbingan dan konseling yaitu ibu Siti Rahma, S.Pd dan Ibu Febrisa Rahim, S.Pd. 
Bedasarkan skor angket yang diperoleh oleh masing-masing siswa. Berikut ini adalah uraian penurunan kecemasan berpendapat siswa:

1. Kecemasan berpendapat AN memiliki nilai pre-test(Sebelum diberi layanan) sebesar 9 dengan kategori tinggi dan nilai post-test (Setelah diberi layanan) 58 dengan kategori rendah. Dengan demikian AN mengalami penurunan kecemasan berpendapat sebesar 37 atau $39.85 \%$

2. Kecemasan berpendapat $B$ memiliki nilai pre-test (Sebelum diberi layanan) sebesar 98 dengan kategori tinggi dan nilai post-test (Setelah diberi layanan) 57 dengan kategori rendah. Dengan demikian $\mathrm{B}$ mengalami penurunan kecemasan berpendapat sebesar 41 atau $41.83 \%$

3. Kecemasan berpendapat IS memiliki nilai pre-test (Sebelum diberi layanan) sebesar 103 dengan kategori tinggi dan nilai post-test (Setelah diberi layanan) 54 dengan kategori rendah. Dengan demikian IS mengalami penurunan kecemasan berpendapat sebesar 51 atau $47.57 \%$

4. Kecemasan berpendapat MA memiliki nilai pre-test (Sebelum diberi layanan) sebesar 98 dengan kategori tinggi dan nilai post-test (Setelah diberi layanan) 52 dengan kategori rendah. Dengan demikian MA mengalami penurunan kecemasan berpendapat sebesar 46 atau $46.93 \%$

5. Kecemasan berpendapat PR memiliki nilai pre-test (Sebelum diberi layanan) sebesar 95 dengan kategori tinggi dan nilai post-test (Setelah diberi layanan) 57 dengan kategori rendah. Dengan demikian PR mengalami penurunan kecemasan berpendapat sebesar 38 atau $40 \%$

6. Kecemasan berpendapat RY memiliki nilai pre-test (Sebelum diberi layanan) sebesar 98 dengan kategori tinggi dan nilai post-test (Setelah diberi layanan) 54 dengan kategori rendah. Dengan demikian RY mengalami penurunan kecemasan berpendapat sebesar 41 atau $44.89 \%$

7. Kecemasan berpendapat RR memiliki nilai pre-test (Sebelum diberi layanan) sebesar 96 dengan kategori tinggi dan nilai post-test (Setelah diberi layanan) 59 dengan kategori rendah. Dengan demikian RR mengalami penurunan kecemasan berpendapat sebesar 37 atau $38.54 \%$

8. Kecemasan berpendapat ST memiliki nilai pre-test (Sebelum diberi layanan) sebesar 97 dengan kategori tinggi dan nilai post-test (Setelah diberi layanan) 53 dengan kategori rendah. Dengan demikian ST mengalami penurunan 
kecemasan berpendapat sebesar 44 atau $45.36 \%$.

Bedasarkan uraian diatas dapat terlihat penurunan kecemasan berpendapat siswa sebelum dan sesudah diberikan layanan konseling kelompok pendekatan rational emotif behaviour terapy. Sebelum diberikan layanan konseling kelompok pendekatan rational emotif behaviour terapy terdapat rata-rata kecemasan berpendapat yang dialami oleh 8 siswa tersebut $97.5 \%$ dan setelah diberikan layanan konseling kelompok pendekatan rational emotif behaviour terapy diketahui rata-rata kecemasan berpendapat siswa adalah $55.5 \%$. Perubahan penurunan interval kecemasan berpendapat 8 siswa tersebut $43.07 \%$.Dan perubahan terendah terdapat pada RR $38.54 \%$ dan perubahan tertinggi terdapat pada IS $47.57 \%$.

Nilai kritis $\mathbf{J}$ untuk uji jenjang bertanda Wilcoxon untuk $\mathrm{n}=8, \alpha=0,05$ pengujian dua arah J0,05 =4. Oleh karena J (17.5>4). Sesuai dengan kriteria penerimaan dan penolakan hipotesis, hipotesis diterima jika J hitung >Jtabel. Dengan demikian dinyatakan ada pengaruh pemberian layanan konseling kelompok pendekatan rational emotif behaviour terapy terhadap kecemasan berpendapat siswa kelas VII-5 SMP Negeri 3 Tanjungbalai tahun ajaran 2016/2017. Atau hipotesis diterima. Hal ini juga dapat dilihat dari perolehan skor rata-rata siswa yang mengalami penurunan yaitu dari 97.5 (pre- test) menjadi 55.5 (post -test) dengan perubahan penurunan interval kecemasan berpendapat siswa sebesar $43.07 \%$.

Pengadaan konseling kelompok kepada siswa baru pertama sekali dilakukan di sekolah tersebut. Sehingga pada awal para siswa mengikuti kegiatan kelompok mereka masih terlihat bingung. Meski bingung mereka tetap mengikuti tahap demi tahap kegiatan konseling kelompok dengan sangat antusias. Hasilnya meski baru pertama sekali dilakukan kegiatan konseling kelompok berjalan dengan lancar disetiap pertemuan. Hal ini terlihat dari penilaian pada RPLBK yang dibuat oleh peneliti pada pertemuan bimbingan kelompok memperoleh nilai 95,71 , pada pertemuan kedua dilakukan penilaian konseling kelompok pertama dengan nilai 92,3, penilaian konseling kelompok kedua diperoleh nilai 95,51 dan penilaian konseling kelompok ketiga diperoleh 98,12. Hasil tersebut telah memenuhi kriteria penilaian yang telah ditetapkan yaitu baik $\geq 80$; Cukup 46-79; kurang $\leq$ 45.

Berdasarkan tahapan yang dikemukakan Mungin EddyWibowo (2005 :86) mengenai tahapan proses 
konseling kelompok yaitu tahap permulaan, tahap transisi, tahap kegiatan, tahap pengakhiran dan tahap pencapaian agenda maka peneliti telah melaksanakan semua tahapan dengan baik. Dengan adanya tahapan-tahapan dalam konseling kelompok maka konseling kelompok yang dilakukan berjalan lebih terarah.

Demikian pula dengan kecemasan berpendapat, Sumadinata (2004:23) mengatakan bahwa kecemasan adalah keadaan yang dialami seseorang yang merasa khawatir karena menghadapi situasi yang tidak bisa memberikan jawaban yang jelas, tidak bisa mengharapkan sesuatu pertolongan, dan tidak ada harapan yang jelas akan mendapatkan hasil. Kecemasan berpendapat yang dialami siswa juga dilihat dari faktor penyebab kecemasan berpendapat yang diungkapkan oleh Savitri Ramaiah (2003:11) yaitu kecemasan berpendapat siswa karena faktor lingkungan, emosi yang ditekan dan sebab-sebab fisik.

Setelah siswa yang kecemasan berpendapat tersebut diberikan tindakan berupa konseling kelompok rational emotif behaviour terapy terjadi penurunan tingkat kecemasan berpendapat pada siswa sehingga dapat dikatakan penerapan konseling kelompok rational emotif behaviour terapy berhasil dilakukan.
Dengan adanya keberhasilan ini maka penelitian yang dilakukan oleh peneliti terdahulu sehubungan dengan penerapan konseling kelompok untuk mengurangi kecemasan berpendapat siswa dapat dipercaya. Adapun penelitian sebelumnya yang dilakukan oleh beberapa peneliti terdahulu bahwa penerapan konseling kelompok rational emotif behaviour terapy dapat mengurangi kecemasan berpendapat, dimana terdapat 3 penelitian yang dapat dijadikan pembanding dalam melakukan peneilitian ini yaitu, (1) Afifah (2016) Pengaruh layanan konseling kelompok dengan pendekatan Rational emotif behaviour terapy terhadap kecemasan berbicara sisw SMA Negeri 1 Siantar Narumoda Tahun Ajaran 2016/2017, (2) Triyoso Adi Puspito (2) Layanan konseling kelompok dengan pendekatan Ratioal Emotif Behaviour Terapy (REBT) untuk pengembangan kemampuan berfikir positif pada siswa kelas VIII MTsN Sale Rembang tahun ajaran 2014/2015. Dengan adanya penelitian terdahulu yang telah pernah menggunakan konseling kelompok rational emotif behaviour terapy dalam mengurangi kecemasan berpendapat maka konseling kelompok rational emotif behaviour terapy sangat efektif digunakan peneliti dalam melakukan penelitian ini. 
Dengan demikian, terbukti konseling kelompok rational emotif behaviour terapy dapat membantu menyelesaikan masalah siswa terutama masalah kecemasan berpendapat. Hal ini sejalan pula dengan tujuan pengadaan konseling kelompok rational emotif behaviour terapy dalam Ellis (2005) adalah membantu indvidu menyadari bahwa mereka dapat hidup dengan lebih rasional dan lebih produktif, membantu individu untuk mengubah kebiasaan berfikir dan tingkah laku yang merusak diri, mendukung konseli untuk menjadi lebih toleran terhadap diri sendiri, orag lain, dan lingkungannya. Serta tujuan konseling kelompok yang dikemukakan oleh Ohlsen sebagaimana dikutip Winkel dan Astuti (2004:559), tujuan konseling kelompok adalah : (1) Masing-masing klien memahami dirinya dengan baik dan menemukan dirinya sendiri. Bedasarkan pemahaman diri klien lebih menerima dirinya sendiri dan lebih terbuka kepada aspek- aspek postif dalam kepribadiannya. (2) Para klien lebih peka terhadap kebutuhan orang lain dan lebih mampu meghayati perasaan orang lain.Kepekaan dan penghayatan ini akan membuat mereka peka terhadap kebutuhan psikologis diri sendiri. (3) Masing-masing klien menetapkan dan menghayati makna dari kehidupan manusia sebagai kehidupan bersama, yang mengandung tuntutan menerima orang lain dan harapan akan diterima orang lain. (4) Masingmasing klien semakin menyadari bahwa hal -hal yang memprihatinkan bagi dirinya kerap juga menimbulkan ras prihatin kepada orang lain.

Sebelum dilaksanakan layanan konseling kelompok rational emotif behaviour terapy, kecemasan berpendapat siswa tergolong tinggi dengan rata -rata 97,5 \%. Hal ini dibuktikan dari hasil angket dimana skor siswa menunjukan kecemasan berpendapat yang tinggi. Dalam hal ini peneliti menggunakan layanan konseling kelompok rational emotif behaviour terapy untuk mengatasi kecemasan berpedapat tersebut.

Setiap rumusan masalah yang peneliti buat juga dialami oleh masing -masing siswa dan mereka juga dapat mengatasinya setelah konseling kelompok rational emotif behaviour terapy dilakukan, yakni : (1) AN memilki nilai pre test sebesar 95 dengan kategori tinggi dimana AN selalu gemetara ketika diminta berpendapat didepan kelas, tidak berani bertanya kepada guru pada pelajarn yang tiak dipahaminya setelah diberi perlakuan AN memiliki nilai post-test sebesar 58 dengan demikian IP mengalami penurunan kecemasan berpendapat sebesar $39 \%$ dimana AN 
sudah berani member pendapat di kelas dan bertaya kepada guru entang pelajaran yang tidak dipahaminya. (2) B memiliki nilai pre-test sebesar 98 dengan kategori tinggi dimana B menganggap bahwa guru dan teman-teman sekelasnya tiak suka jia dia bertanya dan bmengutarakan pendapat didepan kels, tidak sdkit dari temantemannya yang mengejek jika dia menanggapi pertanyaan guru karna jawaban nya salah sehingga dia tidak mau lgi untuk berpendapat didepan kelas setelah diberi perlakuan $\mathrm{B}$ memiliki nilai post-test sebesar 57 dengan demikian B mengalami penurunan sebesar $41.83 \%$ dimana B sudah tidak menghiraukan lagi ejekan teman-temannya, karna dia yakin belajar itu harus percaya diri dan tidak mudah menyerah. (3) IS memiliki nilai pre-test sebesar 103 dengan kategori tinggi dimana IS menjadi anak yang pendiam karna mengalami tekanan dari orangtua dan teman-teman sekelasnya, bahka ketka guru bertanya dia aya iam dan tunduk IS tidak pernah menjawab pertanyaan guru setelah diberi perlakuan IS memiliki nilai post-test sebesar 54 dengan demikian IS mengalami penurunan kecemasan berpendapat sebesar $47.57 \%$ dimana IS sudah tidak pendiam lagi, IS selalu mengkomunikasikan masalahnya kepada guru BK, IS juga mulai memberanikan diri untuk menjawab pertanyaan gurunya. (4) MA memiliki nilai pre-test sebesar 98 dengan kategori tinggi dimana MA takut bertanya kepada guru setelah diberi perlakuan MA memiliki nilai post-test sebesar 52 dengan demikian MA mengalami penurunan kecemasan berpendapat sebesar $46.93 \%$ dimana MA sudah berani bertanya dan tidak takut bertaya pada gurunya lagi. (5) PR memiliki nilai pre-test sebesar 95 dengan kategori tinggi dimana PR menganggap bahwa bertanya dan berpendepat dikelas itu sia-sia karna tidak akan didenar oleh guru, setelah diberi perlakuan PR memiliki nilai post-test sebesar 57 dengan demikian PR mengalami penurunan kecemasan berpendapat sebesar $40 \%$ dimana PR sudah tidak menganggap berpendapat dikelas itu adalah hal yang sia-sia, dia semakin rajin bertanya an menanggapi pertanyaan dikelas(6) RY memiliki nilai perilaku pre-test sebesar 98 dimana RY tidak suka berpendapat dikelas karna lebih sering di ejek sama teman-temannyaketika berbicara didpepan kelas setelah diberi perlakuan RY memiliki nilai Post-test sebesar 54 dengan demikian RY mengalami penurunan kecemasan berpendapat sebesar $44.89 \%$ dimana RY sudah berani menyampaikan pendapat didepan kelas da tidak lagi meghiraukan ejekan teman-temannya (7) 
RR memiliki nilai pre-test sebesar 96 dimana RR tidak suka berpendapat dikelas karna RR memang tidak tau apa yang ingin ia sampaikan, dia lebih suka mengejek temannya yang berbicara didepan kelas daripada berpendapat didepan kkelas setelah diberi perlakuan RR memiliki nilai pos-test sebesar 59 dengan demikian RR mengalami penurunan kecemasan berpendapat sebesar $38.54 \%$ dimana RR sudah merasa bahwa ketika belajar dia harus rajin bertanya dan berpendapat dikelas agar dia mngerti pelajaran dan mendapat nilai yang bagus(8) ST memiliki nilai pre-test sebesar 97 dimana ST sering gemetaran ketika guru memintanya untuk menjawab pertanyaan didepan kelas, dia menjadi kaku dan gugup menjawab pertanyaan setalah diberi perlakuan ST memiliki skor 53 dengan demikian ST mengalami penurunan kecemasan berpendapat sebesar $45.36 \%$ dimana ST sudah tidak gugup dan gemetaran lagi ketika menjawab pertanyaan guru didepan kelas, ST sudah berani bertanya dan menanggapi pertanyn didepan kelas.

Data ini juga diperkuat oleh guru Bimbingan Konseling yang ada di SMP Negeri 3 Tanjungbalai terkhusus observer. Menurut guru bimbingan konseling, perubahan perilaku siswa yang mengikuti kegiatan konseling kelompok pendekatan rationl emotif behaviour sangat begitu tampak dengan keaktifan dan pola perilaku menjadi lebih baik, data tersebut di dapat dari rekap Absen dan penilaian belajar guru bidang studi siswa - siswi SMP Negeri 3 Tanjungbalai dan dari observasi guru bimbingan konseling sendiri.

Hal ini sejalan dengan pendapat Skinner dalam Purwanto, 1990;95 bahwa sebuah perilaku merupakan respon atau reaksi seseorang terhadap rangsangan dari luar, maka kecemasan berpendapat juga dapat berubah dan mengalami penurunan karena adanya rangsangan yang diberikan. Salah satu faktor yang dapat mempengaruhi kecemasan berpendapat siswa adalah melalui faktor eksternal (lingkungan sekolah) yaitu melalui guru bimbingan konseling.Guru Bimbingan konseling memberikan berbagai layanan dan diantaranya adalah layanan konseling kelompok.

Setelah diberikan layanan konseling kelompok rational emotif behaviour terapy diketahui rata-rata kecemasan berpendapat siswa $55.5 \%$ .Perubahan penuruan interval kecemasan berpendapat 8 siswa tersebut $43.07 \%$ dan perubahan terendah terdapat pada $\mathrm{RR}$ $38.54 \%$ dan perubahan tertinggi terdapat 
pada IS $47.57 \%$. Layanan konseling kelompok rational emotif behaviour terapy dalam penelitian ini adalah layanan yang diterapkan untuk membantu siswa untuk berfikir dan berbuat rasional. Siswa dilatih untuk berfikir ddan berbuat rasional dengan memberanikan diri dan membuang rasa takut ketika berpendapat didepan kelas. Peneliti juga membantu memperhatikan mereka setiap harinya.

Pelaksanaan layanan konseling kelompok pendekatan rational emotif behaviour terapy ini yakni siswa secara bersama-sama mencari solusi atas masalah kecemasan berpendapat yang mereka alami dan berupaya menerapkan upayaupaya yang telah mereka sepakati. Dengan demikian, berdasarkan tujuan penelitian ini Untuk mengetahui pengaruh konseling kelompok pendekatan rational emotif behaviour terapy terhadap kecemasan berpendapat siswa SMP Negeri 3 Tanjungbalai tahun ajaran 2016 / 2017 Kota Tanjungbalai, maka peneliti telah menemukan terdapat pengaruh konseling kelompok pendekatan rational emotif behaviour terapy terhadap kecemasan berpendapat siswa SMP Negeri 3 Tanjungbalai tahun ajaran 2016 / 2017.

\section{KESIMPULAN}

Hasil analisa data yang didapatkan dalam penelitian ini adalah nilai Jhitung $=$ 17,5 dengan $a=0.05$ dan $\mathrm{n}=8$, maka berdasarkan daftar, Jtabel $=4$. Dengan demikian Jhitung > Jtabel $(17,5>4)$. Artinya hipotesis diterima. Data Pre-test diperoleh rata-rata 97,5 sedangkan setelah pemberian layanan konseling kelompok pendekatan REBT (Post-test) diperoleh rata-rata 55,5. Artinya skor rata-rata siswa setelah mendapat layanan konseling kelompok pendekatan REBT lebih rendah daripada sebelum mendapatakan layanan konseling kelompok pendekatan REBT. Perubahan penurunan interval kcmasan berpendapat siswa setelah diberi layanan konseling kelompok dengan pendekatan REBT sebesar 42 atau 43.07\%. Hal ini menunjukkan ada pengaruh layanan konseling kelompok dengan pendekatan REBT terhadap kecemasan berpendapat siswa dikelas VII-5 SMP Negeri 3 Tanjung balai T.A 2016-2017 atau hipotesis diterima.

\section{SARAN}

Berdasarkan kesimpulan diatas, maka sebagai tindak lanjut penelitian ini disarakan hal-hal sebagai berikut:

Diharapkan kepada kepala sekolah untuk lebih memfasilitasi ruangan kegiatan layanan bimbingan konseling, sebagai upaya membantu dalam program pendidikan sekolah, serta meperhatikan segala kondisi psikologis siswa dan bekerjasama dengan guru bidang studi 
untuk menciptakan suasana belajar mengajar yang menyenangkan.

Untuk mengatasi berbagai permasalahan yang terjadi pada siswa, diharapkan para pendidik khususnya guru mampu menciptakan kondisi dan suasana belajar mengajar yang menyenangkan sehingga siswa tidak merasa ketakutan untuk mengutarakan pendapatnya, dan guru BK dapat memaksimalkan pelayanan dalam berbagai layanan terkhusus layanan konseling kelompok, serta harus lebih peka terhadap masalah-masalah yang dialami siswa dan terus memperhatikan perubahan yang dialami siswa.

Diharapkan kepada orang tua agar lebih memperhatikan pendidikan anaknya, sering berkonsultasi dengan guru BK tentang sikap belajar anak disekolah.

Diharapkan siswa lebih serius dalam mengikuti proses belajar mengajar agar siswa mampu menggapai prestasi dan cita-cita. Serta siswa dharapkan untuk berani mengungkapkan permasalahan belajr yang dialaminya kepada guru BK.

\section{DAFTAR PUSTAKA}

Arikunto, Suharismi. 2010. Prosedur Penelitian suatu pendekatan praktik. Jakarta: Rineka Cipta

Wibowo, Mungin Edi. 2005. "Konseling Kelompok Perkembangan”. Semarang: UNNES Press.

Winkel, W.S. 1991. Bimbingan dan Konseling di Institusi Pendidikan. Jakarta: Gramedia
Prayitno. 1995. "Layanan Bimbingan dan Konseling Kelompok (Dasar dan Profil)" Jakarta: Ghalia Indonesia.

Prayitno dan Erman Amti. 1994. Dasardasar Bimbingan dan Konseling. Jakarta: Rineka Cipta

Zayiroh. 2007. Keefektifan Layanan Bimbingan Kelompok dalam Meningkatkan Perilaku Komunikasi Antar Pribadi Siswa Kelas X Sma Negeri 1 Ungaran Tahun Pelajaran 2006/2007. Skripsi UNPAD.fakultas ilmu pendidikan. (Online). Diakses pada 12 desember 2006

Corey, G. 2012. The Theory and Practice of Group Counseling. Ed. Pacific Grove,California: Brooks/Cole

Salahudin, Anas. 2012. Bimbingan dan Konseling. Jakarta: Pustaka Setia

Rochman,K. 2010. Kecemasan . Jakarta:Pustaka budi

Kurnanto, Edi. 2013. Konseling Kelompok. Bandung: Alfabeta

Prayitno. 2004. Layanan bimbingan Kelompok Dan Konseling Kelompok. Padang: Universitas Negeri Padang

Novita,E. 2006. Efektivitas Metode Pembelajaran Gotong Royong (Cooperative Learning) Untuk Menurunkan Kecemasan Siswa Dalam Menghadapi Pelajaran Matematika. Education Psychology Journal.1. vol 4 - 10

Laksmiwati.H.2003. Pengembangan Prosedur Implementasi Strategi Cognitive Restructuring dan Systematic Desensitization Untuk 
Mengatasi Kecemasan Berbicara di Muka Umum. Jurnal Psikologi Pendidikan dan Bimbingan Fakultas Ilmu Pendidikan UNESA. Vol 5. 1- 19

David, D. (in press). Rational emotive behavior therapy. In R. L. Cautin \& S. O. Lilienfeld

(Eds.), Encyclopedia of Clinical Psychology. Hoboken, NJ: WileyBlackwell.

David, D. forthcoming 2014. Rational Emotive Behavior Therapy. In D. S. Dunn (Ed.), Oxford Bibliographies in Psychology. New York, NY: Oxford University Press.

David, D. Lynn, S., \& Ellis. A. (2010). Rational and irrational beliefs. Implications for research, theory, and practice. New York, NY : Oxford University Press.

David, D. 2014. The Empirical Status of Rational Emotive Behavior Therapy (REBT) Theory \& Practice. Journal of psychology.113. 